\title{
KECERDASAN SPIRITUAL MEMODERASI GAYA KEPEMIMPINAN DAN BUDAYA ORGANISASI PADAKINERJA PENYUSUN LAPORAN AKUNTABILITASKINERJA INSTANSI PEMERINTAH (LAKIP)
}

\author{
Noldy Imanuel H. Ratu ${ }^{1}$ \\ Maria Mediatrix Ratna Sari ${ }^{2}$ \\ I G. A. M. Asri Dwija Putri ${ }^{3}$
}

${ }^{1}$ Fakultas Ekonomi \& Bisnis Universitas Udayana (Unud), Bali, Indonesia

${ }^{1}$ Email: noldhy.ratu81@ gmail.com

${ }^{2}$ Fakultas Ekonomi \& Bisnis Universitas Udayana (Unud), Bali, Indonesia

${ }^{3}$ Fakultas Ekonomi \& Bisnis Universitas Udayana (Unud), Bali, Indonesia

\begin{abstract}
ABSTRAK
Penerapan akuntabilitas publik merupakan cara untuk mempertanggungjawabkan keberhasilan maupun kegagalan dalam rangka mencapai misi organisasi merupakan latar belakang penelitian ini.Tujuan penelitian ini untuk mengetahui pengaruh gaya kepemimpinan dan budaya organisasi pada kinerja penyusun LAKIP dengan dimoderasi oleh kecerdasan spiritual. Sampel yang dipakai pada penelitian ini yaitu nonprobability samplingdengan tekniksensus.Responden penelitian ini berjumlah 80 orang. Data primer yang digunakan pada penelitian ini dituangkan melalui pernyataan berupa kuesioner. Uji hipotesis digunakan analisis regresi moderasi.Hasil pengujian hipotesis membuktikankinerja penyusun LAKIP dipengaruhi oleh gaya kepemimpinan dan budaya organisasi.Pengaruh budaya organisasi pada kinerja penyusun laporan akuntabilitas kinerja instansi pemerintah mampu dimoderasi oleh kecerdasan spiritual, sedangkan pengaruh gaya kepemimpinan pada kinerja penyusun laporan akuntabilitas kinerja instansi pemerintah tidak mampu dimoderasi oleh kecerdasan spiritual.
\end{abstract}

Kata kunci: kinerja penyusun laporan akuntabilitas kinerja instansi pemerintah, gaya kepemimpinan, budaya organisasi, kecerdasan spiritual.

\begin{abstract}
The adoption of public accountability is a way to account for success or failure in order to achieve the organization's mission is the background of this research. The purpose of this study to determine the influence of leadership style and organizational culture on the performance of the compilers LAKIP moderated by spiritual intelligence. The sample used in this research is nonprobability sampling with census technique. Respondents of this study amounted to 80 people. Primary data used in this study is poured through a statement in the form of questionnaires. Hypothesis test used moderation regression analysis. Hypothesis testing results prove the performance of LAKIP compilers influenced by leadership style and organizational culture. The influence of organizational culture on the performance of government accountability performance reporting reporter can be moderated by spiritual intelligence, while the influence of leadership style on performance of accountability report reporter of government agency performance can not be moderated by spiritual intelligence.
\end{abstract}

Keywords : performance report compilers accountability performance of government agencies, leadership style, organizational culture, spiritual intelligence. 


\section{PENDAHULUAN}

Penerapan sistem good governance merupakan kebutuhan penyelenggaraan pemerintahan, dalam rangka mempertanggungjawabkan amanah rakyat. Sistem Akuntabilitas Kinerja Instansi Pemerintah (SAKIP) merupakan sistem perencanaan dan pertanggungjawabanmutlak yang harus diberikan oleh setiap pemerintahan sebagaimana diatur dalam Peraturan Presiden No. 29 Tahun 2014 yang berkaitan dengan pencapaian misi dan tujuan organisasi.

Keluarnya penerapan sistem SAKIP, maka dalam Laporan Akuntabilitas Kinerja Instansi Pemerintah (LAKIP) bergeser suatu pemahaman tentang "seberapa besar dana yang telah dan akan dihabiskan" menjadi "seberapa besar kinerja yang telah dihasilkan dan kinerja tambahan yang diperlukan, agar tujuan yang telah ditetapkan pada akhir periode bisa tercapai”. Sistem akuntabilitas kinerja instansi pemerintah dan akuntabilitas publik merupakan bentuk pertanggungjawaban yang saling berkaitan. (Mardiasmo, 2002) menyatakanpemberian informasi dan disclosure atas aktivitas dan kinerja keuangan pemerintah kepada para stakeholder yang berkepentingan merupakan bentuk akuntabilitas publik pemerintah. Terdapat empat aspek pertanggungjawaban yang mestinya dipenuhi setiaporganisasi pemerintahan yaitu, pertanggungjawaban dalam aspek program (program accountability), aspek proses (process accountability), aspek kejujuran dan hukum (accountability for probity and legality), dan aspek kebijakan (policy accountability) Ellwood (1993).

Hasil evaluasi LAKIP tahun 2014 terhadap keseluruhan kabupaten/kota di Indonesia yang berjumlah 492, menunjukkan bahwa hanya empat kabupaten/kota yang meraih predikat $\mathrm{B}$, sedangkan 150 kabupaten/kota meraih predikat $\mathrm{CC}$. 
Kategori hasil evaluasi LAKIP dikelompokkan menjadi empat, yaitu AA (memuaskan), A (sangat baik), B (baik), CC (cukup baik/memadai), C (agak kurang), dan D (kurang) dan penanggungjawab evaluasi tersebut dilakukan oleh Kementerian Pendayagunaan Aparatur Negara dan Reformasi Birokrasi Republik Indonesia.

Berdasarkan evaluasi akuntabilitas kinerja pemerintah kabupaten/kota tahun 2013, Kabupaten Sumba Tengah mendapat predikat D. Mengindikasikan bahwa pemerintah Kabupaten Sumba Tengah kurang dalam memenuhi nilai akuntabilitas kinerja yang baik dan hal ini menuntut kinerja ekstra dari tim penyusun agar hasil penyusunan LAKIP Kabupaten Sumba Tengah dapat lebih baik pada tahun-tahun ke depan. LAKIP KabupatenSumba TengahTahun 2013 mencerminkancapaiankinerja sasaran-sasaranstrategisdari sisi akuntabilitaskinerja di tahun 2013, oleh karena itu diharapkanperkembangandan kemajuan pencapaian sasaran-sasaran strategis dari tahun ke tahun dapat meningkat.

Beberapa permasalahanAKIP di Kabupaten Sumba Tengah terjadi karena belum adanya Standar Operating Prosedure (SOP) tentang pengumpulan data kinerja, adanya Indikator Kinerja Utama(IKU) yang belum mampu mengukur kinerja, penyajian sasaran dalam dokumen Penetapan Kinerja(PK) yang belum selarasdengan dokumen RencanaStrategis(Renstra) SKPD dan hal yang paling penting adalah capaiankinerjatim penyusun LAKIP yang belum optimal. Permasalahantersebutsangat berpengaruhsehingga penilaian AKIP jauh dari harapan.

Pentingnya relasi antara tujuan yang direncanakan dan kinerja yang dicapai merupakan inti goal-setting theory(Locke, 1968). Konsep dasarnya yaitu 
seseorang dengankemampuanmelaksanakan tujuan yang diinginkan oleh organisasi, secara otomatis akan merubahkondisikerjanya.Pencapaian atas sasaran (tujuan) mempunyai pengaruh yang sangat besar pada perilaku pegawai dan kinerja dalam organisasi (Luneburg, 2011).

Kinerja entitas sektor publik adalah suatu desain multidimensional yang terdiri dari beberapa faktor antara lain (1) Individu, yang didalamnya mencakup pengetahuan, keterampilan (skill), kepercayaan diri, kemampuan, komitmen dan motivasi dari masing-masing individu, (2) Kepemimpinan, yang terdiri dari dukungan dari team leader, kemampuan dalam memberikan dorongan, arahan, dan semangat (3) Tim, yang mencakup pemberian semangat dan motivasi oleh anggota dalam tim, rasa saling percaya sesama anggota tim, dan kekompakan, (4) Sistem, yaitu desain dari pekerjaan, budaya kinerja dalam organisasi, dan sarana serta prasarana yang ada dalam organisasi, dan (5) Situasional, yang meliputi perubahan kondisi lingkungan yang datang baik dari dalam maupun dari luar organisasi (Mahmudi, 2010).

Beberapa faktordapat mempengaruhi kinerja penyusun LAKIP di Kabupaten Sumba Tengah antara lain yaitu gaya kepemimpinan dan budaya organisasi. Penelitian tentang gaya kepemimpinan dan budaya organisasi terhadap kinerja pegawai telah banyak dilakukan dengan hasil yang berbeda-beda. Penelitian oleh Rahayu (2014), Sugeng (2014), Wahyuni (2015), membuktikan kinerja pegawai sangat dipengaruhi oleh gaya kepemimpinan dan budaya organisasi. Kemudian penelitian yang dilakukan Masrukhin dan Waridin (2006), menunjukkan gaya kepemimpinan tidak berpengaruh pada kinerja pegawai, dan penelitian tentangbudaya organisasi terhadap kinerja pegawai yang dilakukan oleh 
Trisnaningsih (2007) dan memperoleh hasil yang tidak signifikan, sedangkan penelitian oleh Kim dan Yu (2004), Oparanma (2010), Tseng (2010),dan Zain et al., (2009) terkait pengaruh budaya organisasi pada kinerja cakupannya luas, dan hasilnya tidak meyakinkan karena terjadi perbedaan dan masalah definisi, struktur dan desain.

Hasil penelitian yang tidak konsisten pada variabel gaya kepemimpinan dan variabel budaya organisasi mendorong peneliti untuk meneliti kembali variabel tersebut dengan memasukkan variabel kecerdasan spiritual sebagai variabel pemoderasi. Peneliti menduga ada faktor kontingensi yang memengaruhi hubungan antara gaya kepemimpinan dan budaya organisasipada kinerja penyusun akuntabilitas kinerja instansi pemerintah. Pendekatan kontingensi melalui variabel moderasi dan mediasi merupakan cara yang digunakan untuk merekonsiliasi hasil yang saling saling bertentangan (Murray, 1990). Telaah penelitian menyatakan bahwa faktor kondisional seperti kultur, organisasional, interpersonal, dan individual dapat menjadi variabel pemoderasi (Brownell, 1982).

Kecerdasan spiritual (Spiritual Quotient disingkat SQ)dipilih sebagai variabel moderasi karena merupakankemampuan manusiadalam menyelesaikanpermasalahan makna dan nilai dalam kehidupan, yaitu kemampuan menempatkan sikap dan perilaku pada konteks yang lebih universal, dan juga kemampuanyang memandangsuatu tindakan atau kehidupan seseorang lebih bermakna dibandingkan dengan yang lain. Dalam spiritualitasterkandungnilai kebenaran yang hakiki yang terkait dengan tujuan dari kehidupan manusia, sering dibandingkan dengan sesuatu yang yang bersifat duniawi. Ulum 
danPurnamasari(2015) menyatakan bahwa tingkat spiritualitasseseorang akan membuatnya untuk lebih berpikir inovatif, mempunyai pengetahuan yang luas, dapat membuat aturan atau bahkan mengubahnya, yang pada akhirnya menjadikan individu tersebut bekerja lebih baik.

Tingkat keberhasilan seseorang secara keseluruhan selama periode tertentu dalam melaksanakan tugas berbanding dengan berbagaikemungkinan, seperti standar hasil kerja, target dan sasaran atau kriteria yang ditentukanyang telah disepakati bersama merupakan suatu kinerja (Rivai, 2005:14). Penelitiantentangkinerja telahbanyak dilakukanoleh beberapa penelitisepertiWijayadan Akbar (2013), Antipovadan Antipov(2014),MichelidanNeely(2010), Yuen dan Ng (2012), sehinggamemberiwawasanbaru pada perkembangankinerjadi instansipemerintah.

Terdapat empat masalah penelitian yang akan dirumuskan yaitu, Apakah gaya kepemimpinan mempunyai pengaruh pada kinerja penyusun laporan akuntabilitas kinerja instansi pemerintah Kabupaten Sumba Tengah; Apakah budaya organisasi berpengaruh pada kinerja penyusun laporan akuntabilitas kinerja instansi pemerintah Kabupaten Sumba Tengah; Apakah pengaruh gaya kepemimpinan pada kinerja penyusun laporan akuntabilitas kinerja instansi pemerintah Kabupaten Sumba Tengah mampu dimoderasi oleh kecerdasan spiritual; dan Apakah pengaruh budaya organisasi pada kinerja penyusun laporan akuntabilitas kinerja instansi pemerintah Kabupaten Sumba Tengah mampu dimoderasi oleh kecerdasan spiritual. 


\section{TINJAUAN TEORITIS DAN HIPOTESIS}

\subsection{TeoriGoal-Setting}

Teori goal-setting atau teori penetapan tujuan oleh Locke (1968) adalah teori yang menekankan perlunya hubungan antara tujuan dan hasil yang dicapai.Teori ini menjelaskantentangkomitmen seseorang pada tujuan yang telah ditetapkan. Semakin tinggi komitmen seorang individu untuk mencapai tujuan yang ditetapkan, maka akan berpengaruh pada tindakan dan konsekuensi kinerjanya(Robbins, 2008).Untuk mencapai tujuannya seseorang harus memiliki komitmen yang tinggi, oleh karena itu komitmen tersebut selayaknya akan mempengaruhi setiap tindakan dan konsekuensi kerjanya.Pencapaian atas sasaran (tujuan) mempunyai pengaruh yang sangat besar pada perilaku pegawai dan kinerja dalam organisasi (Luneburg, 2011). Penelitian oleh Kusuma (2013) menemukan bahwa goal-setting mempunyai pengaruh kuat pada ketetapan anggaran. Pedoman atas kegiatan organisasi dalam bentuk keuangan yang mengandung aktivitas selama periode tertentu dituangkan dalam sebuah anggaran yang kemudian akan dipertanggungjawabkan melalui laporan akuntabilitas instansi pemerintah (Yanti dan Sari, 2015)

\subsection{Kinerja}

Keberhasilan individu secara keseluruhan dengan rentang waktu tertentu dalam menjalankan pekerjaan dengan segala permasalahan dan kemugkinan lain, seperti target, sasaran dan standar keberhasilan yang telah disepakati sebelumnya merupakan kinerja yang ingin dicapai oleh setiap individu (Rivai, 2005: 14) . Selain itu kinerja dapat didefinisikan sebagai modelkeberhasilanatas berbagai 
aktifitas, program dan kegiatan sertakebijaksanaanuntukmencapaitujuan, sasaran, maupun pencapain misi dan visi organisasi (Putri, 2015).

\subsection{Akuntabilitas Kinerja Instansi Pemerintah}

Ghartey (1987) mendefinisikan akuntabilitas sebagai keadaan yang dapat dipertanggungjawabkan, tujuan akuntabilitas adalah untuk menemukan jawaban atas apa yang ditanyakandalam hubungannya dengan pelayanan yaitu apa, siapa, yang mana, mengapa, kemana, dan bagaimana sebuah pertanggungjawaban harus dilaksanakan.Akuntabilitas adalah wujud kewajibanbaik individu maupun organisasi untuk mempertanggungjawabkan keberhasilan ataukegagalan dalam mencapai tujuan dan sasaran-sasaran atas penyelesaian berbagai program dan kegiatan yang telah dipercayakan oleh stakeholder dalam rangka mencapai misi organisasi telahditetapkan melalui sistem pertanggungjawaban secara periodik (Ulum, 2004:40).

\subsection{Gaya Kepemimpinan}

Achmad (2007) menyatakan gaya kepemimpinan merupakanbentukperilaku secara keseluruhan atas tindakan seorang atasan kepada bawahannya, baik yang nampak maupun yang tidak nampak. Ardana et al.(2011: 181) menyatakan bahwa bentuk perilaku seorang atasan dipengaruhi oleh banyakaspekantara lain, harapan, nilai-nilai, persepsi, asumsi, maupun sikap yang ada dalam diri atasan tersebut. White (2015) kepemimpinan adalah masalah paling penting yang dihadapi pekerjaan tiap hari dalam organisasi, pemimpin dengan prinsip bertanggung jawab akan memberi komando yang terarah pada bawahan, sedangkan masalah lainnya akan mengurus dirinya sendiri. 


\subsection{Budaya Organisasi}

Ikatan budaya pada kehidupan sehari-hari dalam bermasyarakat tidak dapat dilepaskan begitu saja, budaya akanmembedakan satu golongan dengan golongan lain dalam hal bertindak dan berinteraksi untuk menyelesaikan satu pekerjaan (Abdullahdan Arisanti, 2010). Berjalannya sebuah organisasi yang baik akan memungkinkan individu merasa termotivasi untukbelajar, berkembang, dan memperbaiki diri dengan ditunjang oleh budaya yang kuat dan positif. Dalam organizational cultureterdapatberbagaiperangkat penting yang terdiri dari, norma atau aturan, sikap atau perilaku, dan sebuah keyakinanbesar yang dimiliki bersama oleh seluruh anggota dalam organisasi (Stoner et al., 1996).

\subsection{Kecerdasan Spiritual}

Munandir (2001: 122), menyatakan kecerdasan berkaitan dengan kemampuan individudalam memecahkan masalah yang sedang dialami, terutama masalah yang menuntut kemampuan berpikir lebih. Spiritual adalah suatu sikap dasar manusia untuk mengembangkan nilai-nilai moral dan harga dirinya serta prinsip memiliki yang tinggi. Suatu keadaan dimana manusia dalam kesadarannya dapat terhubung langsung dengan Sang Pencipta, atau apa pun yang menjadi kepercayaan dalam imannya. Spiritualitas dapat diartikan juga sebagai moral, kejiwaan, kerohanian, kebatinan, dan mental.

\subsection{Hipotesis}

\subsubsection{Pengaruh Gaya Kepemimpinan pada Kinerja Penyusun Laporan Akuntabilitas Kinerja Instansi Pemerintah.}

Path-goal leadership theorymenekankan bagaimana pemimpin dapat memberi pengaruhyang kuat terhadap sasaran kerja yang mengarah kepada 
pencapaian sasaran kepada bawahan (Gomez et al., 2005). Sedarmayanti(2007) menyatakan bahwa gayakepemimpinanmerupakanaturan-aturankeperilakuanbaik yang tercatat maupun tidak yangdipakaioleh atasansaatmemberikan pengaruh padabawahannya.Penelitian oleh Trisnaningsih (2007)menemukanadanyahubunganpositif antara gayakepemimpinandan kinerja pegawai.Kemudian penelitian oleh Rahayu (2014) membuktikan bahwa keberhasilan kinerja pegawai sangat dipengaruhi oleh gaya kepemimpinan. Berdasarkan penelitian yang dilakukan sebelumnya, maka dirumuskan hipotesis yaitu :

$\mathrm{H}_{1}$ : Gaya kepemimpinan berpengaruh positif pada kinerja penyusun laporan akuntabilitas kinerja instansi pemerintah.

\subsubsection{Pengaruh Budaya Organisasi pada Kinerja Penyusun Laporan Akuntabilitas Kinerja Instansi Pemerintah.}

Human relation dalam organisasi merupakan hal yang sangat penting karena dapat menjembatani hubungan antara karyawan dengan sesama karyawan maupun karyawan dengan pimpinan (Kossen, 1986).Budaya organisasiadalah pola dasar yang didalamnya terkandung sebuah sistem nilai yang dibuat dan diterima oleh seluruh anggota organisasi dalambersikapuntuk memecahkan berbagai persoalan, menjadikanpara pegawaidapat beradaptasi dengan baik dan menjadi alat pemersatubagi para anggota organisasitersebut (Kinichi, 2005).Penelitian oleh Rahayu (2014) menunjukkan budaya organisasi signifikan mempengaruhi kinerja pegawai. Kemudian penelitian oleh Ogbonna \& Harris (2000) menunjukkan adanya hubungan yang kuat antara budaya organisasi dan praktek kinerja yang akan bergerak pada pengembangan sumber daya manusia. 
Berdasarkan penelitian yang dilakukan sebelumnya, maka dirumuskan hipotesis yaitu :

$\mathrm{H}_{2}$ : Budaya organisasi berpengaruh positif pada kinerja penyusun laporan akuntabilitas kinerja instansi pemerintah.

\subsubsection{Pengaruh Gaya Kepemimpinan pada Kinerja Penyusun Laporan Akuntabilitas Kinerja Instansi Pemerintah dengan Kecerdasan Spiritual sebagai Pemoderasi.}

Spiritual leadership theorymerupakan kepemimpinan spiritual yang menghadirkan keselarasan, memberdayakan anggota sehingga komitmen organisasi dan kesejahteraan bawahan akan terwujud dalam organisasi tersebut (Fry, 2003). ZohardanMarshall(2007)menyatakan bahwa seseorang dengan kemampuanbersikap fleksibel atau adaptif secara spontan dan aktif merupakan ciri-ciriorang dengantingkat kecerdasanspiritualyang tinggi,dan mempunyai kualitas kehidupan yang tinggi berdasarkan visi, misi dan tujuan yang akan dicapai serta nilai kepemimpinan yang dimilikinya dengan penuh tanggungjawab.Penelitian oleh Ulum danPurnamasari (2015)menyatakan bahwa kinerja pegawai sangat dipengaruhi oleh gaya kepemimpinan dengan kecerdasan spiritual sebagai pemoderasi.Berdasarkan penelitian yang dilakukan sebelumnya, maka dirumuskan hipotesis yaitu :

$\mathrm{H}_{3}$ : Kecerdasan spiritual memperkuat pengaruh gaya kepemimpinan pada kinerja penyusun laporan akuntabilitas kinerja instansi pemerintah.

\subsubsection{Pengaruh Budaya Organisasi pada Kinerja Penyusun Laporan Akuntabilitas Kinerja Instansi Pemerintah dengan Kecerdasan Spiritual sebagai Pemoderasi.}

Pengakuan manusia atas kehidupan dan pekerjaannya akan lebih bermakna pada saat berada dalam sebuah komunitas organisasi merupakan prinsip utama 
spiritual leadership theory(Ashmos dan Duchon, 2000). Khavari(2006), menyatakankecerdasanspiritualmemberikankitamatauntuk menilaisegala masalah dalam sisi positif,dan kebijakan dalam organisasi serta memecahkan dan mengambil keuntungan dari masalah tersebut. Widjaja (1997) menjelaskan budaya organisasidapat meningkatkandan menurunkan tingkat efektivitas yang ada pada nilai-nilaiatau aturan-aturanyang ada dalam suatu organisasi. Penelitian oleh Sabiret al. (2012) menunjukkan bahwa nilai-nilai budaya etika dalam organisasi meningkatkan produktifitas kinerja pegawai.Berdasarkan penelitian yang dilakukan sebelumnya, maka dirumuskan hipotesis yaitu :

$\mathrm{H}_{4}$ : Kecerdasan spiritual memperkuat pengaruh budaya organisasi pada kinerja penyusun laporan akuntabilitas kinerja instansi pemerintah.

\section{METODE PENELITIAN}

Penelitian ini dilakukan pada tahun 2017 dan berlokasi di Kabupaten Sumba Tengah. Alasan dijadikannya Kabupaten Sumba Tengah sebagai lokasi karena peneliti melihat kurang optimalnya penerapan AKIP Pemerintah Kabupaten Sumba Tengah yang berdampak pada kinerja pemerintah dan kinerja penyusun LAKIP.

Dengan menggunakan metode kuantitatif, data dikumpulkan dengan metode survei dengan teknik kuesioner. Regresi moderasi merupakan teknik analisis yang akan digunakan kemudian data akan diolah dengan program SPSS versi 22.0. Sebanyak 80 orang yang terdiri dari, 68 orang pejabat eselon III dan IV yang merupakan penyusun LAKIP pada masing-masing SKPD, ditambah 12 orang dari tim penyusun LAKIP Kabupaten Sumba Tengah merupakan populasi 
dalam penelitian ini. Nonprobability sampling merupakan metode sampling yang digunakan, dengan teknik sampel jenuh/sensus.

Variabel kinerja penyusun laporan akuntabilitas kinerja instansi pemerintah diukur melalui indikator yaitu, (1) Tingkat pengetahuan dan keterampilan pada bidang pekerjaan, (2) Tingkat pemahaman terhadap penyusunan LAKIP, yang terdiri dari sembilan (9) item pernyataan yang dikembangkan dari penelitian sebelumnya oleh Wardhana (2015). Pengukuranindikator pada variabel gaya kepemimpinan berorientasi hasil (achievement oriented leadership) antara lain, (1) Menjelaskan pelaksanaan tugas pada bawahan, (2) Merumuskan tujuan organisasi bersama bawahan,(3) Menjalankan disiplin dalam pelaksanaan tugas kepada seluruh bawahan, (4) Memberikan motivasi kepada bawahan untuk terus melakukan inovasi, dan (5) Menetapkan sasaran yang menantang dan mengharapkan bawahan berprestasi, yang terdiri dari 20 item pernyataan yang dikembangkan dari penelitian sebelumnya oleh Rahayu (2014).

Pengukuran variabel budaya organisasi dilakukan dengan menggunakan indikator yaitu, pertama inisiatif, kreatif dan mengambil risiko, keduafokus pada rincian, ketiga orientasi hasil, keempat motivasiindividu, kelima motivasi pada tim, keenambersikap agresif, dan ketujuhkestabilan, yang terdiri dari 19 item pernyataan yang dikembangkan dari penelitian sebelumnya oleh Prakoso (2016). Sedangkan variabel kecerdasan spiritual diukur melalui indikator yaitu, pertamaindikator kemampuan bersikap fleksibel, keduaindikator kesadaran yang tinggi, ketigaindikatorkemampuan menghadapi penderitaan, keempatindikatormampu menghadapi rasa sakit, kelimaindikatormampu 
memahami tujuan hidup, keenamindikatorengganmerugikan orang, ketujuhindikatorselalu berpikir logis, kedelapan indikatorsenang bertanya dan mencari tahu, kesembilanindikatorkepemimpinan yang penuh tanggungjawab. Kesembilan indikator tersebut dituangkan dalam bentuk pernyataan kuesioner yang dikembangkan dari penelitian sebelumnya oleh Ulum dan Purnamasari (2015).

Pengujian instrumen penelitian dilakukan dengan uji validitas dan reliabilitas. Setelah pengujian pertama lulus, selanjutnya dilakukan analisis data dengan melakukan pengujian normalitas, heterokedastisitas dan multikolinearitas. Pengujian hipotesis selanjutnya akan dilakukan dengan menggunakan regresi berganda untuk mengetahui pengaruh langsung variabel independen terhadap variabel dependen, sedangkan untuk mengetahui ada tidaknya efek moderasi dilakukan dengan menginteraksikan variabel bebas dengan variabel moderasi menggunakan MRA.

\section{HASIL DAN PEMBAHASAN}

Kuesioner penelitian mulai disebar 10 Februari 2017 dan dikumpulkan kembali tanggal 28 Februari 2017, dengan masa waktu pengisian selama 12 hari kerja. Adapun hasil rincian kuesioner yang disebar dan yang kembalidisajikanpada Tabel 1.

\section{Tabel 1}

Tingkat Sebaran dan Pengembalian Kuesioner

\begin{tabular}{lcc}
\hline Kuesioner & Jumlah & Prosentase \\
\hline Awal & 80 & $100 \%$ \\
Kembali & 79 & $98,75 \%$ \\
Tidak kembali & 1 & $1,25 \%$ \\
Diolah & 79 & $98,75 \%$ \\
\hline Sumber: Data diolah (2017) & &
\end{tabular}


Sesuai Tabel 1, di atas dapat dilihat bahwa sebanyak 80 kuesioner yang disebar dan tingkat pengembalian kuesioner sebanyak 79 atau 98,75\%, terdapat 1 kuesioner yang tidak kembali, ini disebabkan karena responden tidak mengembalikan dengan alasan sibuk. Berdasarkan penyebaran responden penelitian diketahui terdapat sebanyak 48 orang pria dan 31 orang wanita, dan dengan tingkat pendidikan responden rata-rata mereka yang berpendidikan sarjana (strata satu) yang berjumlah 75 orang.

Pengujian respon bias dilakukan untuk mendapatkan buktiada tidaknya perbedaan yang sangat signifikan terhadap responden yang didatangi langsung dengan responden yang mengirim jawaban sendiri. Analisis lebih lanjut baru dapat dilakukan jika tidak terdapat perbedaan yang signifikan antara kelompokkelompok responden tersebut yang dilakukan melalui uji beda (Badera, 2008: 70).

Hasil pengujian menunjukkan bahwa perbedaan rata-rata melalui F-test untuk masing-masing variabel pada dua kelompok data tidak signifikan dengan nilai $\mathrm{p}$-value $>0,05$ terhadap semua variabel yang diuji. Untuk variabel gaya kepemimpinan $=0,794$, variabel budaya organisasi $=0,614$, variabel kecerdasan spiritual $=0,353$ dan variabel kinerja penyusun laporan akuntabilitas kinerja instansi pemerintah $=0,221$. Dari hasil uji respon bias yang dilakukanantara jawaban responden dari kelompok responden yang didatangi langsung dengan kelompok responden yang jawaban kuesionernya dikirim, tidak diketemukanadanyaperbedaan yang signifikan karena p-value > 0,05 sehingga pengujian dapat dilanjutkan.Hasil uji respon bias pada kuesioner yang dibagi dilihat pada Tabel 2 . 
Tabel2

Hasil Uji Respon Bias Variabel Penelitian

\begin{tabular}{lccccc}
\hline \multicolumn{1}{c}{ Variabel } & Kode & N & Mean & F & Signifikansi \\
\hline Gaya Kepemimpinan & 1 & 56 & 3,81 & 0,068 & 0,794 \\
& 2 & 23 & 3,85 & & 0,614 \\
Budaya Organisasi & 1 & 56 & 3,97 & 0,257 & 0,353 \\
& 2 & 23 & 4,06 & & 0,874 \\
Kecerdasan Spiritual & 1 & 56 & 3,38 & & \multirow{2}{*}{0,221} \\
Kinerja Penyusun Laporan & 2 & 23 & 3,53 & & \\
Akuntabilitas Kinerja & 1 & 56 & 3,95 & & \\
Instansi Pemerintah & 2 & 23 & 4,16 &
\end{tabular}

Uji validitas pada variabel gaya kepemimpinan, budaya organisasi, kecerdasan spiritual dan kinerja penyusun laporan akuntabilitas kinerja instansi pemerintah menunjukkan hasil berada di atas 0,3 dengan tingkat signifikansi < 0,05 dan ini berarti indikator dari semua variabel dianggap syarat validitas. Hasil uji reliabilitas dengan nilai Cronbach's Alpha> 0,6 menunjukkan bahwa semua instrumen dalam penelitian ini telah memenuhi syarat reliabilitas.

Pengukuran karakteristik variabel penelitian melalui uji statistik deskriptif dilakukan untuk melihat nilai terendah, tertinggi, nilai mean dan standar deviasi. Ringkasan hasil statistik deskriptif disajikan pada Tabel 3.

Tabel3

\section{Hasil Statistik Deskriptif}

\begin{tabular}{clccccc}
\hline No & Variabel & N & Min & Max & Rata-rata & $\begin{array}{c}\text { Standar } \\
\text { Deviasi }\end{array}$ \\
\hline 1 & Gaya Kepemimpinan $\left(\mathrm{X}_{1}\right)$ & 79 & 57 & 100 & 82,61 & 8,727 \\
2 & Budaya Organisasi $\left(\mathrm{X}_{2}\right)$ & 79 & 51 & 92 & 77,20 & 8,489 \\
3 & Kecerdasan Spiritual $\left(\mathrm{X}_{3}\right)$ & 79 & 25 & 45 & 37,13 & 3,546
\end{tabular}




\begin{tabular}{|c|c|c|c|c|c|c|}
\hline 4 & $\begin{array}{l}\text { Kinerja Penyusun Laporan } \\
\text { Akuntabilitas Kinerja } \\
\text { Instansi Pemerintah (Y) }\end{array}$ & 79 & 25 & 44 & 35,84 & 3,953 \\
\hline
\end{tabular}

Sumber: Data diolah (2017)

Nilai rata-rata $X_{1}$ sebesar 82,61, hal ini berarti bahwa dari 20 pernyataan variabel gaya kepemimpinan rata-rata responden berkompeten dan mempunyai kemampuan dalam menyelesaikan tugasnya sebagai penyusun perencanaan dan pelaporan AKIP. Nilai rata-rata $X_{2}$ sebesar 77,20, hal ini dimaknai bahwa rata-rata responden memiliki budaya organisasi yang kuat dalam menjalankan tugas, pokok dan fungsinya sebagai penyusun perencanaan dan pelaporan AKIP.Nilai rata-rata $\mathrm{X}_{3}$ sebesar 37,13 , hal ini dimaknai bahwa rata-rata responden menempatkan spiritualitasyang tinggi dalam menjalankan tugas, pokok dan fungsinya sebagai penyusun perencanaan dan pelaporan AKIP.Nilai rata-rata X3sebesar 35,84,pernyataan-pernyataan variabel kinerja penyusun laporan akuntabilitas kinerja instansi pemerintah mengindikasikan kinerja yang tinggi dari rata-rata responden dalam menyusun perencanaan dan pelaporan AKIP.

Untuk hasil pengujian normalitas penelitian ini dengan nilai Asymp. Sig. $0,377>0,05$, dengan demikian syarat normalitas data yang digunakan telah terpenuhi. Berdasarkan hasil uji Glejser menunjukkan bahwa model yang digunakan dalam penelitian ini bebas heterokedastisitas, dimana nilai signifikansi untuk variabel gaya kepemimpinan $=0,184$ dan budaya organisasi $=0,182$ yang keduanya berada di atas 0,05 . Hasil uji multikolinearitas dengan nilai tolerance untuk dua variabel bebas yaitu 0,550 atau melebihi angka 0,1 kemudian 1,820 untuk nilai VIF atau $<10$ dari aturan yang disyaratkan, hal ini menunjukkan data bebas dari multikolinearitas. 
Tabel 4

Regresi Berganda

\begin{tabular}{|c|c|c|c|c|c|}
\hline \multirow[t]{2}{*}{ Variabel. } & \multicolumn{2}{|c|}{$\begin{array}{l}\text { Untandardized } \\
\text { Coefficients. }\end{array}$} & \multirow{2}{*}{$\begin{array}{c}\text { Standardized } \\
\text { Coefficients. } \\
\text { Beta }\end{array}$} & \multirow[t]{2}{*}{$\mathrm{t}$} & \multirow[t]{2}{*}{ Sig. } \\
\hline & B & Std. Error & & & \\
\hline Constant & 3,769 & 2,527 & & 1,492 & 0,140 \\
\hline $\begin{array}{l}\text { Gaya } \\
\text { Kepemimpinan }\left(\mathrm{X}_{1}\right)\end{array}$ & 0,078 & 0,038 & 0,173 & 2,044 & 0,044 \\
\hline $\begin{array}{l}\text { Budaya } \\
\text { Organisasi }\left(\mathrm{X}_{2}\right)\end{array}$ & 0,332 & 0,039 & 0,712 & 8,436 & 0,000 \\
\hline Ftest & \multicolumn{2}{|c|}{89,607} & & & 0,000 \\
\hline $\mathrm{R}^{2}$ & \multicolumn{2}{|c|}{0,702} & & & \\
\hline Adjusted $\mathrm{R}^{2}$ & \multicolumn{2}{|c|}{0,694} & & & \\
\hline
\end{tabular}

Sumber: Data diolah (2017)

Hasil Tabel 4di atasmenjelaskanbeberapa temuan penelitian yaitu,pertama nilai Adjusted $\mathrm{R}^{2}$ sebesar 0,694 menunjukkan 69,4\% variasi perubahan kinerja penyusun LAKIP dijelaskan oleh variabel bebas gaya kepemimpinan dan budaya organisasi, sedangkan 30,4\% merupakan variabel selain dalam model. Kedua, hasil nilai $\mathrm{F}_{\text {hitungyaitu }}$ 89,607 pada taraf signifikansi 0,000 yang berada di bawah $\alpha$ $=0,05(\alpha=5 \%)$,yang menunjukkan bahwa model dalam penelitian telah lolos uji goodness of fit sehingga uji hipotesis dapat dilanjutkan. 


\section{Tabel 5 \\ Moderated Regression Analysis}

\begin{tabular}{|c|c|c|c|c|c|}
\hline \multirow[t]{2}{*}{ Variabel. } & \multicolumn{2}{|c|}{$\begin{array}{l}\text { Unstandardized. } \\
\text { Coefficients. }\end{array}$} & \multirow{2}{*}{$\begin{array}{c}\text { Standardized. } \\
\text { Coefficients. } \\
\text { Beta. }\end{array}$} & \multirow[t]{2}{*}{$\mathrm{t}$} & \multirow[t]{2}{*}{ Sig. } \\
\hline & B & Std. Error & & & \\
\hline Constant & $-2,681$ & 15,896 & & $-0,169$ & 0,867 \\
\hline Gaya Kepemimpinan $\left(\mathrm{X}_{1}\right)$ & 1,509 & 0,417 & 3,332 & 3,624 & 0,001 \\
\hline $\begin{array}{l}\text { Budaya } \\
\text { Organisasi }\left(\mathrm{X}_{2}\right)\end{array}$ & $-1,099$ & 0,479 & $-2,361$ & $-2,296$ & 0,025 \\
\hline Kecerdasan Spiritual $\left(\mathrm{X}_{3}\right)$ & 0,196 & 0,434 & 0,176 & 0,453 & 0,652 \\
\hline Moderasi $1\left(\mathrm{X}_{1} \cdot \mathrm{X}_{3}\right)$ & $-0,039$ & 0,011 & $-5,171$ & $-3,430$ & 0,001 \\
\hline Moderasi $2\left(\mathrm{X}_{2} \cdot \mathrm{X}_{3}\right)$ & 0,039 & 0,013 & 4,947 & 3,026 & 0,003 \\
\hline Ftest & \multicolumn{2}{|c|}{42,890} & & & 0,000 \\
\hline $\mathrm{R}^{2}$ & \multicolumn{2}{|c|}{0,746} & & & \\
\hline Adjusted $\mathrm{R}^{2}$ & \multicolumn{2}{|c|}{0,729} & & & \\
\hline
\end{tabular}

Sumber: Data diolah (2017)

Hasil Tabel 5 di atas terhadap analisis regresi moderasidapat dijelaskan bahwa interaksiantara kecerdasan spiritual dan gaya kepemimpinan serta budaya organisasi menunjukkan adanya peningkatan nilai Adjusted $\mathrm{R}^{2}$ sebesar 0,729 yang berarti 72,9\% variasi perubahan kinerja penyusun LAKIP mampudiinterpretasikan oleh gaya kepemimpinan dan budaya organisasi dengan kecerdasan spiritual sebagai pemoderasi, sedangkan $27,1 \%$ merupakan variabel yang tidak dimasukkan dalam model. Uji F-test dengan nilai 42,890 pada nilai signifikan $0,000<\alpha=0,05(\alpha=5 \%)$, mengindikasikan bahwa model penelitian memenuhi syarat goodness of fit untuk pembuktian hipotesis. 
Pengujian hipotesis pertama menunjukkan bahwa hipotesis diterima, hal ini dibuktikan dengan nilai signifikansi 0,044 berada di bawah $\alpha=0,05$, yang berarti gaya kepemimpinan mempunyai pengaruh yang signifikan pada kinerja penyusun laporan akuntabilitas kinerja instansi pemerintah. Nilai koefisien gaya kepemimpinan $\left(\mathrm{X}_{1}\right)$ 0,078 bermakna bahwa apabila variabel gaya kepemimpinan meningkat maka variabel kinerja penyusun laporan akuntabilitas kinerja instansi pemerintah juga akan meningkat. Semakin tinggi kepemimpinan seseorang kepada bawahan maka cenderung meningkatkan kinerja pegawai pada organisasi tersebut. Pemimpin yang dapat memberi pengaruh kepadabawahan untuk melakukan pekerjaandengan lebih baik dalam rangka tercapainya tujuan organisasi merupakan gaya kepemimpinan yang baik, karena pada hakikatnya organisasi pemerintahandibentukagar dapat memberikan pelayanan kepada masyarakat (Wahyuni, 2015).Tugas seorang pemimpin adalah membantu dan memberikan arah dan tujuan kepada para anggotanya dalam rangka menjamin kesesuaian antara tujuan anggota dan tujuan kelompok (Darmaji et al, 2013). Hasil uji hipotesis ini sesuai dengan penelitian oleh Rahayu (2014) yang membuktikan gaya kepemimpinan mempunyai pengaruh signifikanpada kinerja pegawai.

Pengujian hipotesis kedua sesuai Tabel 4 di atas, dilakukan untuk mengetahui pengaruh budaya organisasi pada kinerja penyusun laporan akuntabilitas kinerja instansi pemerintah.Hasil uji membuktikan nilai signifikan 0,000 berada di bawah $\alpha=0,05$, bermakna budaya organisasi berpengaruh positif pada kinerja penyusun laporan akuntabilitas kinerja instansi pemerintah. Nilai Koefisien budaya organisasi $\left(\mathrm{X}_{2}\right)$ adalah 0,332 yang berarti apabila variabel 
budaya organisasi meningkat, maka variabel kinerja penyusun laporan akuntabilitas kinerja instansi pemerintah juga akan meningkat. Tingginya kualitas dari budaya organisasiakan sangat berpengaruh terhadap kualitas pelayanan publik itu sendiri sehingga kinerja pegawai dan organisasi akan berjalan produktif. Organisasi dengan budaya yang kuat akan terkandung sebuah normanorma aturan yang akan dianut oleh anggotanya, yang dapatmempunyai pengaruh terhadap cara berpikir, bekerja dan berperilaku para anggotanya sehingga menghasilkan kinerja yang maksimal (Osborne dan Plastrik, 2000).Hal yang paling penting dalam mengembangkan budaya organisasi yang kuat adalah adanya human relation dari orang-orang yang berada dalam sebuah organisasi, sehingga menghadirkan sebuah budaya yang efektif dan dapat meningkatkan kinerja organisasi tersebut (Susanti et al, 2014).Hipotesis kedua diterima, hasil uji hipotesis ini sesuai dengan penelitian oleh Rahayu (2014) yang membuktikan budaya organisasi mempunyai pengaruh signifikanpada kinerja pegawai.

Analisis regresi moderasi sesuai Tabel 5 di atas dilakukan untuk menguji hipotesis ketiga dengan tujuan membuktikan pengaruh gaya kepemimpinan pada kinerja penyusun laporan akuntabilitas kinerja instansi pemerintah mampu dimoderasi oleh kecerdasan spiritual $\left(\mathrm{X}_{1} \mathrm{X}_{3}\right)$. Hasil uji moderasi menunjukkan tingkat signifikansi 0,001 di bawah dari nilai $\alpha=0,05$ dengan nilai koefisien sebesar minus 0,039, ini berarti bahwa kecerdasan spiritual memperlemah pengaruh gaya kepemimpinan pada kinerja penyusun laporan akuntabilitas kinerja instansi pemerintah, dengan demikian hipotesis ini tidak diterima.Artinya bahwa pemimpin dalam menerapkan suatu gaya kepemimpinan walaupun dengan tingkat kecerdasan spiritual yang tinggi dan memiliki kemampuan bersikap adaptif 
(spontan dan aktif) atau yang dikenal dengan sikap fleksibel, tidak mampu meningkatkan kinerja suatu organisasi sebab penerapan gaya kepemimpinan pada suatu situasi belum tentu sesuai dengan situasi lainnnya. Hal lain yang menyebabkan lemahnya pemimpin dengan tingkat kecerdasan spiritual tinggi dalam meningkatkan kinerja organisasi disebabkan tingginya faktor politik dan kakunya sistem dalam birokrasi yang kadangkala bertolak belakang dengan tujuan organisasi.

Pengujian hipotesis keempat sesuai Tabel 5 di atas juga untuk membuktikan pengaruh budaya organisasi pada kinerja penyusun laporan akuntabilitas kinerja instansi pemerintah mampu dimoderasi oleh kecerdasan spiritual $\left(\mathrm{X}_{2} \mathrm{X}_{3}\right)$. Hasil uji moderasi menunjukkan tingkat signifikansi 0,003 di bawah nilai $\alpha=0,05$ dengan nilai koefisien yaitu 0,039 , ini berarti bahwa kecerdasan spiritual memperkuat pengaruh budaya organisasi pada kinerja penyusun laporan akuntabilitas kinerja instansi pemerintah (LAKIP), yang bermaknahipotesis diterima.Penelitian ini sesuai dengan yang dilakukan oleh Lousyiana dan Harlen (2015) serta Syauta et al. (2012) yang menyatakan bahwa budaya organisasi terdiri dari keikhlasan, keterlibatan, konsistensi, adaptabilitas dan misi yang dapat mempengaruhi tinggi rendahnya kinerja. Organisasi dengan budaya yang kuat mempengaruhi kerja pegawai yang akhirnya dapat meningkatkan kinerja individu dan organisasi.Penelitian ini juga mendukung penelitian Zohar dan Marshall (2007) yang menginterpretasikan kecerdasan spiritual sebagai kecerdasan yang mampu menilai setiapperbuatan atau sikap hidup seseorang akan lebih bermakna dari pada hal lainnya, selain itu kecerdasan spiritual juga dianggap sebagai kemampuandalam menghadapi dan memecahkan 
persoalan baik nilai maupun makna, dalam arti mampumemposisikansikap dan perilaku dalam konteks arti yang lebih luas.Seorang pegawai yang melaksanakanpenerapan spiritualitas dalam lingkungan organisasinya akan merasakan kehidupan dan pekerjaannya lebih berarti, sehingga dapatmemberi motivasi pegawai lain untuk melakukan pekerjaanyang lebih optimal(Ashmos dan Duchon, 2000).Individu dengan tingkat spiritualitas yang baik, ketika menerima pekerjaan baik banyak atau sedikitakan merasabukan sebuah masalah besar, karena hal yang sangat pentingyaitu pekerjaan yang diterimanya akan dilakukan dengan tulus dan iklassertamemikul tanggung jawab pekerjaan itu dengan sebaikbaiknya, sehingga akan menghasilkan kinerja yang tinggi.

\section{KESIMPULAN}

Beberapa kesimpulan yang diperolehatas hasil penelitian ini yaitu pertama, gaya kepemimpinan memberikan pengaruh positif pada kinerja penyusun laporan akuntabilitas kinerja instansi pemerintah, hal ini bermakna bahwa semakin tinggi gaya kepemimpinan para pejabat di lingkungan Pemerintah Kabupaten Sumba Tengah maka kinerja penyusun laporan akuntabilitas kinerja instansi pemerintah semakin meningkat. Kedua, budaya organisasi berpengaruh positif pada kinerja penyusun laporan akuntabilitas kinerja instansi pemerintah, hal ini bermakna bahwa semakin kuat budaya organisasi yang dibangun oleh para pegawai di lingkungan Pemerintah Kabupaten Sumba Tengah maka akan meningkatkan kinerja penyusun LAKIP.Ketiga,gaya kepemimpinan pada kinerja penyusun laporan akuntabilitas kinerja instansi pemerintah tidak diperkuat oleh kecerdasan spiritual, hal ini bermakna penerapan gaya kepemimpinan pada suatu situasi belum tentu sesuai dengan situasi lainnnya walaupun pemimpin dengan tingkat 
kecerdasan spiritual yang tinggi dan memiliki kemampuan bersikap fleksibel, (4) Kecerdasan spiritual memperkuat pengaruh budaya organisasi pada kinerja penyusun laporan akuntabilitas kinerja instansi pemerintah, hal ini bermakna seorang pegawai yang memiliki kecerdasan spiritual dapat membangun budaya yang kuat di lingkungan organisasinya dan memotivasi pegawai lain untuk bekerja lebih optimal.

\section{SARAN}

Saran yang dapat diberikan baik kepada Pemerintah Kabupaten Sumba Tengah maupun kepada peneliti selanjutnya yang berkaitan dengan kinerja yaitu pertama, kepada Pemerintah Kabupaten Sumba Tengah, khususnya para pimpinan SKPD agar menitikberatkan pada kualitas kinerja penyusun laporan dengan sebaik-baiknya agar laporan yang disampaikan memberikan manfaat dan hasil yang berdaya guna, hal ini sesuai hasil penelitian yang membuktikan bahwa dengan tingginya kepemimpinan seorang atasan kepada bawahan dapat meningkatkan kinerja tim penyusun laporan dan kinerja SKPD. Kedua, melalui pendekatan human relation theory, diharapkan Pemerintah Kabupaten Sumba Tengah dapat mengembangkan sebuah budaya organisasi yang efektif dan kuat dalam meningkatkan kinerja. Budaya organisasi yang kuat dapat meningkatkan kinerja walaupun disadari bahwa penerapan budaya dalam organisasi tidak mudah dilakukan. Ketiga, dalam upaya peningkatan produktifitas organisasi, diharapkan agar para pegawai di Kabupaten Sumba Tengah melakukan pendekatan spiritual dengan cara mengadakan seminar-seminar keagamaan atau melakukan kegiatan keagamaan. Seseorang dengan spiritualitas yang kuatakancenderung menjadi seseorang yang penuh dengan pengabdian, bertanggungjawab atas pekerjaan dan 
dapat memberikan inspirasi terhadap orang lain sehingga tujuan yang ditetapkan akan menghasilkan kinerja baik. Keempat, Pemerintah Kabupaten Sumba Tengah perlu menerapkan konsep dasar goal-setting theory yang menitikberatkan pada relasi antara tujuan dan hasil yang ingin dicapai agar hasil yang dicapai tersebut dimaknai sebagai sebuah keberhasilan individu maupun organisasi dalam penerapan sistem good governance sebagai wujud pertanggungjawaban pemerintah kepada masyarakat yang berkaitan dengan akuntabilitas publik. Kelima, peneliti selanjutnya dapat menambahkan variabel lain seperti penerapan anggaran berbasis kinerja, kompetensi, pelatihan dan komitmen organisasi untuk menguji pengaruhnya pada kinerja pegawai. 


\section{REFERENSI}

Abdullah\& Arisanti H.2010.Pengaruh Budaya Organisasi, Komitmen Organisasi dan Akuntabilitas Publik terhadap Kinerja Organisasi.Jurnal EKOBISUniversitas Syah Kuala Banda Aceh. Vol. 9(2): 118-134.

Achmad, Arief. 2007. Memahami Berpikir Kritis. Bandung: Artikel Pendidikan.

Antipova,T.,\&Antipov,A.2014.PerformanceMeasurementinPublicSector. Journal of Global Conferenceon Businessand FinanceProceedings. Vol.9(1): 133-137.

Ardana, IK., Mujiati, Ni Wayan.\&Utama,IWMudiartha. 2011. Manajemen Sumber Daya Manusia. Denpasar: Graha Ilmu.

Ashmos, D. P., \& Duchon, D. 2000. Spirituality at work: A conceptualization and measure. Journal of Management Inquiry, Vol.9(2): 134-145.

Badera, ID.N. 2008. "Pengaruh Kesesuaian Hubungan Corporate Governance dengan Budaya Organisasi Korporasi terhadap Kinerja Perusahaan” (disertasi). Yogyakarta: Universitas Gadjah Mada

Brownell, P. 1982. A Field Study Examination Of Budgetary Participation And Locus Of Control. The Accounting Review. Vol. 57: 766-777.

Darmaji, Laras Tri. Atikasari, Nisrina., Saputra, M., Darmawan \& Yunarti, D., Aprianing. 2013. Pendekatan Situasional: Teori Blanchard, Fiedler, Path Goal dan Subtitusi. Makalah Kepemimpinan, Fakultas Ilmu Administrasi. Universitas Brawijaya.

Ellwood, Sheila. 1993.Praktek Penyelengaraan Pemerintah di Daerah. Bima Aksara: Jakarta.

Fry, L. W. 2003. Toward a Theory of Spiritual Leadership. The Journal of Leadership Quarterly.Vol. 4: 693-727.

Ghartey, J. B. 1987. Crisis, Accountability \& Development in the Third World. London: Avebury.

Gomez, Mejia R., Luis, David B. Balkin \& Robert L. Cardy. 2005. Management: People, Performance and Change, McGrawHill/Irwin, New York. 
Khavari.K.,

A.2006.TheArtofHappiness:MenciptakanKebahagiaanSetiapKeadaan.Jakarta:P

T SerambillmuSemesta.

Kim, S., Lee J., \&Yu K. 2004. Corporate culture and organizational performance. Journal of Managerial Psychology.Vol. 19(4): 340-359.

Kinichi, Angelo. 2005. Perilaku Organisasi, Seri1. Jakarta : Salemba.

Kossen, Stan. 1986. Aspek Manusia Dalam Organisasi. Penerbit: Erlangga, Jakarta.

Kusuma, I. G. 2013. "Pengaruh Kejelasan Sasaran Anggaran, Komitmen Organisasi dan Ketidakpastian Lingkungan pada Ketepatan Anggaran”. (tesis). Denpasar: Univesritas Udayana.

Locke, E. A. 1968. Toward Theory of Task Motivation \& Incentives. International Journal American Institutes of Research.Vol.16 (3): 57-89.

Lousyiana, Tiara T.,\& Harlen. 2015. Pengaruh Gaya Kepemimpinan \& Budaya Organisasi pada Kepuasan Kerja dan Kinerja Perawat di Rumah Sakit islam Ibnu Sina Pekan Baru. Jurnal Manajemen Bisnis Universitas Riau. Vol. 7(3).

Luneburg, F. C. 2011. Goal Setting Theory and Task of Motivation. International Journal of Management, Business and Administration, Vol. 15(1):1-6.

Mahmudi, 2010. Manajemen Kinerja Sektor Publik. UPP Sekolah Tinggi Ilmu Manajemen YKPN: Yogyakarta.

Mardiasmo. 2002.Otonomi dan Manajemen Keuangan Daerah.Penerbit:ANDI, Yogyakarta.

Masrukhin, \& Waridin. 2006. Pengaruh Motivasi Kerja, Kepuasan Kerja,Budaya Organisasi, \& Kepemimpinan Terhadap Kinerja Pegawai. Jurnal Ekonomi dan Bisnis. Vol.7(2): 197-209.

Micheli P. \& Neely A.2010.Performance Measurement in The Public Sector in England: Searching The Golden Thread.Journal Public AdministrationReview. Vol. 70(4): 591-600.

Munandir. 2001. Enslikopedia Pendidikan. Cetakan I. Malang: UM Press.

Murray, D., K.1990. The Performance Effect of Participative Budgeting: An Integration of Intervening and Moderating Variables. JournalBehavioralResearch in Accounting. Vol. 19: 104-123. 
Ogbonna, E. \& Harris, L. 2000. Leadership style, organizational culture \& performance: Empirical Evidence from UK Companies. InternationalJournal of Human Resourcesmanagement. Vol. 11(4): 766-788.

Oparanma , A.O. 2010. The Organizational Culture and Corporate Performance in Nigeria. International Journal of African Studies. Vol. 3: 34-40.

Osborne, David \& Plastrik, Peter. 2000. Banishing Bureauracracy, The Five Strategies for Reinventing Government. A Plume Book.

Prakoso, Veriyanto Adi. 2016. "Pengaruh Kompetensi dan Budaya Organisasi pada Kinerja Penyusun Laporan Keuangan Satuan Kerja Kementerian/Lembaga Dengan Komitmen Organisasi Sebagai Variabel Intervening”. (tesis). Denpasar: Universitas Udayana.

Putri, I G. A. M., Asri Dwija. 2015. SDM, Good Corporate Governance, dan Kinerja Perusahaan. Jurnal Piramida Universitas Udayana. Vol. 11(1): 29-34.

Rahayu, Sri. 2014. "Pengaruh Gaya Kepemimpinan dan Budaya Organisasi Terhadap Kinerja Pegawai Melalui Kepuasan Kerja Sebagai Variabel Intervening (Studi pada Badan Pusat Statistik Sulawesi Barat)". (tesis). Jakarta: Universitas Terbuka.

Rivai, V. 2005. Manajemen SDM untuk Perusahaan dari Teori ke Praktek. SeriPertama. PT. Raja Grafindo Persada.

Robbins, S., \&Judge P. 2008.Perilaku Organisasi, Buku 2. Salemba Empat, Jakarta.

Sabir, S., Iqbal, J. J., \& Rehman, U. K. 2012. Impact of Corporate Ethical Values on Ethical Leadership and Employee Performance. International Journal of Businessand Social Science.Vol. 3(2): $163-171$.

Sedarmayanti.,2007.Manajemen SDM: Reformasi Birokrasi dan Manajemen PNS.Buku 1. PT. Refika Aditama.

Sugeng, Mochamad. 2014. "Pengaruh Gaya Kepemimpinan, Budaya Organisasi dan Kepuasan Kerja Terhadap Kinerja Pegawaipada Sekretariat Daerah Kota Sibolga”. (tesis). Jakarta: Universitas Terbuka.

Susanti, Eka C. Putri, Musadieq, M. A. \& Ruhana, Ika. 2014.Pengaruh HumanRelation (Hubungan Antar Manusia) danKondisi Lingkungan Kerja Terhadap Kinerja Karyawan. Jurnal Ilmu AdministrasiUniversitas Brawijaya.

Stoner, James A. F., Freeman, R. E., Gilbert J. R., \&Daniel. R. 1996. Manajemen, Seri Pertama. PT Bhuana Ilmu Populer. 
Syauta, J. H., Eka T., Margono S., \&Solimun. 2012. The Influence of Organizational Culture,OrganizationalCommitment to Job Satisfaction and Employee Performance.International Journal of Business and Management Invention.Vol.1(1): 69-76.

Trisnaningsih, S. 2007. Independensi Auditor dan Komitmen Organisasi Sebagai Mediasi Pengaruh Pemahaman Good Governance, Gaya Kepemimpinan dan Budaya Organisasi terhadap Kinerja Auditor. SNA X Makassar.

Tseng, Shu-Mei. 2010.The Correlation Between Organizational Culture and Knowledge Conversion on Corporate Performance. Journal of Knowledge Management.Vol. 14(2): 269-284.

Ulum, M. D.Ihyaul. 2004. Sebuah Pengantar Akuntansi Sektor Publik. Jakarta.

Ulum, Roudhotul \& Purnamasari P. 2015. Kecerdasan Spiritual Memoderasi Pengaruh Gaya Kepemimpinan,Kelebihan Peran dan Konflik Peran pada Kinerja Auditor. Simposium Nasional Akuntansi 18Universitas Sumatera Utara.

Wahyuni, E. 2015. Pengaruh Budaya Organisasi \& Gaya Kepemimpinan pada Kinerja Pegawai Bagian Keuangan Organisasi Sektor Publik Dengan Motivasi Kerja Sebagai Variabel Intervening. Jurnal Nominal.Vol. 4(1).

Wardhana, Gede Ary Surya. 2015. "Pengaruh Kompetensi pada Akuntabilitas Kinerja Instansi Pemerintah dengan Komitmen Organisasi sebagai Variabel Moderasi”. (tesis). Denpasar: Unversitas Udayana.

Widjaja, A. W. 1997. Ilmu Komunikasi Pengantar Studi. Jakarta: Bina Aksara.

Wijaya,A. H. C, \& Akbar, R. 2013. The Influence of Information, OrganizationalObjectivesand Targets,and ExternalPressure Towards the Adoption of PerformanceMeasurementSystem in Public Sector. Journal of Indonesian Economyand Business. Vol.28 (1): 62-83.

White, Walt W. 2015.The Leverage of Leadership.Journal of Organizational Culture, Communications and Conflict.Vol. 19(2).

Yanti,Ni Wayan M., \&Sari, Maria M. Ratna., 2015. Asimetri Informasi Sebagai Pemoderasi PengaruhPartisipasi Penganggaran dan Kejelasan Sasaran Anggaran pada Senjangan Anggaran. Jurnal Akuntansi Unud. Vol. 15(1): 257-285.

Yuen, P. P., \& Ng, A. W. 2012. Towards a balancedperformancemeasurement systemin a publichealthcare organization.InternationalJournal of HealthCare QualityAssurance.Vol.25(5).

Zain, Z.M., Ihsak, R., \&Ghani E., K. 2009. The Influence of Corporate Culture on Organisational Commitment: A Study on a Malaysian Listed Company, 
Noldy Imanuel Hama Ratu, Maria Mediatric Ratna Sari dan I G.A.M. Asri Dwija Putri, Kecerdasan ...

EuropeanJournal of Economics, Finance and Administrative Sciences. Vol. 17: 17-25.

Zohar, D., \&Marshall, I. 2007. Spiritual Intelligence (SQ:) The Ultimate of Intelligence. Terjemahan olehR.Astutiet al.,Bandung. PenerbitMizanMediaUtama. 